\title{
Heidegger, Wagner and the History of Aesthetics
}

\author{
Jonathan SALEM-Wiseman
}

Without doubt, Richard Wagner's theoretical writings and his operatic works have received more attention from philosophers and intellectuals than those of any other canonical figure in Western musical history. ${ }^{1}$ In fact, one would be hard-pressed to find another modern artist working in any genre who has captured our attention to the same degree as Wagner. Given that Wagner himself was influenced by the likes of Hegel, Feuerbach, Bakunin, Schopenhauer, and Nietzsche (debatably), this sort of philosophical scrutiny should perhaps come as no surprise. But perhaps no philosopher assigns greater significance to Wagner than Heidegger does, yet in the recent literature almost nothing is even mentioned of this unlikely pairing of musically tin-eared philosopher and philosophically-scattered composer. ${ }^{2}$ On the one hand, Heidegger places Wagner between two seminal thinkers, Hegel and Nietzsche, in his somewhat potted, developmental history of modern aesthetics. On the other hand, given Heidegger's deeply critical account of aesthetics itself as entangled in the history of Western metaphysics, this prominent role must be viewed simultaneously as a back-handed compliment.

In what follows, I want to explore Heidegger's ambivalent relationship to Wagner, first, by situating Heidegger's interpretation of Wagner within the larger framework of his philosophy of art and his powerful critique of aesthetics. In the mid-1930s, at least, Heidegger argued that the reason why we no longer have "great art" any more, why it has become, in Hegel's words, a "thing of the past," (Hegel, Aesthetics 11) is actually due to the demands and prohibitions placed 
upon art by the very aesthetic theories that have governed the West's reflections on art since ancient times. $^{3}$

After establishing this broader context, I want to show, second, why Heidegger believes that music in general is inescapably caught up in this nefarious web of strictly aesthetic prescriptions and restrictions, why it is reducible, ultimately, to the mere stimulation of inner feeling, and why it is, therefore, unable to attain the status of great art, as Heidegger understands this term. Consequently, given the progressive dominance of music in Wagner's operas (not to mention his unfulfilled ambition to write symphonies after Parsifal), they too must fail to attain greatness, and stand instead as remarkable exhibits, if not symptoms, of modern aesthetics.

Much more speculatively, I want to suggest, third, that a possible (yet unacknowledged) motivation of Heidegger's disputes with Wagner, Nietzsche, and, by extension, Schopenhauer, concerns the ultimate nature and origins of Greek tragedy. Like Wagner and Nietzsche, Heidegger devoted himself to the study of Greek tragedy, and his Wagner interpretation of 1936 comes but a year after his famous discussion of Antigone in his Introduction to Metaphysics, and six years before the longer interpretation of Sophocles' play in his lecture course on Hölderlin's hymn "The Ister." This later reading of Antigone, however, clearly registers Heidegger's claims about music that are developed in his Wagner interpretation, for he is adamant in this 1942 lecture course that the choral origins of tragedy in general, when understood properly, have nothing to do with music, but instead reveal that poetry is the essence of tragic drama. The chorus may well have been musical, but its musicality was inessential to the developmental history of tragedy, and could not account for the greatness of the tragedians' art.

For Heidegger, Greek tragedy was a paradigm of great art, the type of art that is no longer possible in modernity due to the baleful influence of aesthetics. However, if tragedy originates, 
as Nietzsche claims, "out of the spirit of music," and if music is already "tainted" due to its nature with the very features that Heidegger discerns in later, aestheticized forms of art, then Heidegger would be compelled to accept that Greek tragedy was not great art after all. Since he does not want to do this, Heidegger must claim instead, as the 1942 lectures make clear, that Nietzsche and others are simply wrong about the origins and essence of tragedy. My goal in this section is not to assert the rightness or wrongness of Heidegger's complex position, but to clarify his "philosophy of music" in light of his interpretation of Greek tragedy. One possible implication of the claim that music already functioned aesthetically prior to the advent of aesthetics itself, however, is that it at least weakens Heidegger's overall narrative about the ruination of practice by theory, which opens up the possibility of great art even within the era of modern aesthetics. This may well be the philosophical price Heidegger pays for saving Greek tragedy from music-lovers like Nietzsche.

Fourth, as an extended conclusion, I want to turn to the music, thereby correcting Heidegger's exclusive focus on Wagner's theoretical writing, and his omission of any meaningful commentary or consideration of Wagner's actual musical dramas. ${ }^{5}$ Heidegger's apparent lack of interest might seem appropriate given his ostensible topic - the history of aesthetics. But this would ignore Heidegger's contemporaneous interpretations of Hölderlin's poetry, interpretations in which a very specific philosophical content is extracted from Hölderlin's poems. In Heidegger's first meditations on poetry, Hölderlin's work is read not qua poetry, but as a repository of Heideggerian-sounding ideas about art in general. With a high degree of hermeneutical finesse, Heidegger brings Hölderlin into his own philosophical orbit: the thinker and poet are made virtually to coincide. As we shall see, even if Hölderin's hymns do not count as "great art" like Greek tragedy, they are exemplary for helping us to understand how art 
itself works, and thus transcend the subjectivistic approach to art characteristic of modern aesthetics. But why are Wagner's operas not "read" in this way? Why are they not scoured for Wagner's philosophical insights? I will suggest that if Heidegger had bothered attending (to) Wagner's Ring cycle especially, he could likewise have discovered a virtual treasure-trove of philosophical themes that remarkably anticipate his own thinking at the time.

From a political perspective, what has been generally overlooked in Heidegger's unsatisfactory and incomplete confrontation with Wagner is the sheer audacity of Heidegger's stance at the very time when Hitler, almost exclusively amongst the Nazi leadership, was pointing to Bayreuth as the epicenter of Germany's cultural renewal. By taking on Wagner while simultaneously championing Hölderlin, Heidegger was at least circuitously challenging Hitler's vision of National Socialism - hardly a gambit without risk. ${ }^{6}$ It is, accordingly, Heidegger's philosophically and politically charged critique of Wagner, music, and what art has become in the modern age, to which I shall now turn.

\section{Great Art and the History of Aesthetics}

In Hitchcock's Vertigo, John "Scottie" Ferguson (played by Jimmy Stewart) is briefly committed to a psychiatric hospital, due to the trauma of watching (who he thinks is) his lover fall to her death after jumping from a high tower. Because Ferguson is depressed, virtually catatonic, his friend Midge Wood (Barbara Bel Geddes) tries to cheer him up by playing Mozart. As she explains,

I had a long talk with a lady in musical therapy ... and she says Mozart is the boy for you. A broom that sweeps the cobwebs away ... I have music for dipsomaniacs, music for melancholiacs, music for hypochondriacs. I wonder what would happen if someone got their files mixed up? (Hitchcock, Vertigo) ${ }^{7}$ 
What this charming scene unwittingly brings to light is, for Heidegger, the culmination of Western aesthetics: the use of art as psychological or physiological stimulant, the conflation of art and pharmacology. For Heidegger, this terminal point was built into the very beginning of the West's attempts to theorize art, and Heidegger will try to explain precisely how this movement unfolded through a series of developmental stages. Before retracing this history, however, it is crucial to understand what Heidegger meant by "great art," the sort of art that could speak for itself, that existed for the Greeks prior to becoming the focus of Plato's theoretical gaze.

Beginning in the1930s, Heidegger devotes a great deal of attention to explaining what art is, and attempts to unpack the difference between the ancient Greeks' relationship to art and that of our own. ${ }^{8}$ In "The Origin of the Work of Art" especially, Heidegger articulates a series of almost-extravagant claims about how the work of art played a truth-disclosing role for the Greeks, and was thus able to "ground history" (Heidegger, "Origin" 77). The Greek temple, for example, was not only the focal point of cultural life, but tacitly performed the ontological task of helping the Greek people understand themselves and their historical world. As Heidegger states, the temple "in its standing there, first gives to things their look and to men their outlook on themselves" (43). In other words, as an example of great art, the temple discloses what the world, ontologically speaking, is like, but it also acts normatively to establish "around itself the unity of those paths and relations in which birth and death, disaster and blessing, victory and disgrace, endurance and decline acquire the shape of destiny for human being" (42). The temple thus reveals to the Greek people just how they should understand their lives and how their world works; it thus makes intelligible that of which the Greeks would otherwise be only dimly or implicitly aware. 
In Heidegger's jargon, what this means is that the great artwork "is the becoming and happening of truth" (71). The truth disclosed by the artwork, however, is not eternal and unchanging, but is rather an historical process according to which the (in this case, ancient Greek) community gains an understanding of its being, an understanding that can be irreversibly lost as the result of "world-withdrawal and world-decay." (41). Today, that ancient world is long gone, and the temple can no longer serve as its "cultural paradigm," which means, strictly

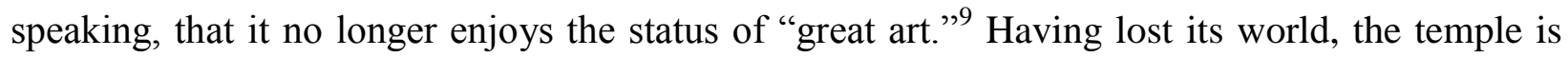
now merely an old relic, a tourist attraction, or at best, an object of theoretical concern for art historians or archeologists. Art is not timeless, after all.

There is much more, obviously, that can be said about what Heidegger means by great art, but that is not my focus. Nor is it my interest to assess the accuracy or validity of Heidegger's claims - either about artworks in general, or the role the temple, for instance, played in the ancient world. From this brief summary, however, we can at least safely glean a few key features of great, "pre-aesthetic," art that can be contrasted with the "aestheticized" art that exists in the modern age. First, the great work of art is truth-disclosive: it makes the world of an historical community intelligible, revealing and clarifying both, as Iain Thomson puts it, "what is and what matters" in that world (Thomson 43). Second, the work is public: it is embedded and woven into the physical environment of a community. Third, the work qua great artwork is historically finite: its greatness is contingent upon the existence of the very world it helps to sustain and nourish, but worlds come and go as the metaphysics of an age gives way and a new understanding of being is inaugurated.

Let me pause here to say a few words about metaphysics in light of its relationship to Heidegger's history of aesthetics — our real quarry. Indeed, what exactly is Heidegger's 
philosophical problem with metaphysics, generally speaking, and aesthetics, in particular? According to Heidegger, metaphysics is concerned with "the being of beings," the universal traits or structures that all beings must possess in order, minimally, "to be." Within a particular culture or form of life (the ancient Greek world, medieval Christian Europe, the modern era), beings "show up" for us as real within a particular horizon of disclosure that has been fixed by the prevailing metaphysics of the age. Being itself, the unfathomable source of these metaphysically circumscribed epochs within which beings become intelligible, is not itself mindor culture-dependent, but the way being reveals itself to any age does depend on human beings. Now, in any epoch, beings are revealed in one dominant way. Heidegger contends that this is not the only way a being can show up and become intelligible or have meaning for us, but by absolutizing the horizon of disclosure, making it the singularly authoritative way in which things can be said to be, all other possible ways of revealing the world are closed off to us, marginalized, pushed aside. ${ }^{10}$ The metaphysics of an age thus represents beings one way only, and blocks off other perspectives. For example, in the modern age, Heidegger claims that beings only show up for us as standing reserve, raw stuff to be pressed into the service of industry and commerce. Since this perspective is absolutized, other possible ways for beings to show up for us are concealed, and worse, we are not even aware that they are concealed. We are thus oblivious to the plenitude of being, to the many other ways the world might be revealed to us.

Now, what metaphysics does for beings, aesthetics does for art. Aesthetics determines exactly those universal features that make a work of art. By fixing the essence of art in this way, aesthetics closes us off to what else the work of art might reveal to us. Heidegger wants to overcome aesthetics in order to free the work of art from its metaphysically fixed horizons. When art becomes, as it has in the modern age, merely a sort of object that can produce certain 
feelings within an observing subject, then its role, quite clearly, has been reduced, especially if we think about those three features of great art that I summarized above.

It might be helpful to contrast Heidegger's claims here with those of Arthur Danto. As Danto famously argues in his 1964 article, "The Artworld," aesthetics is not some belated, theoretical enterprise that takes flight only at dusk; rather, aesthetics actually makes art possible by enabling us to identify it and distinguish it from other mundane objects. Art cannot come into being, following Danto's argument, unless we already have some sense (aesthetics) of what is or is not artistic. Thus, Duchamp's fountain could not have been considered art in the middle ages, just as there could not have been, to use Danto's example, “Etruscan typewriter erasers" (Danto 581). What counts as a work of art, accordingly, is deeply connected with the claims, arguments, judgments, tastes, etc. of a particular, culturally and historically situated, "artworld." Now, Heidegger may well agree with Danto that in the modern epoch, art and aesthetics are deeply entangled. But unlike Danto, Heidegger would claim that this complex relationship actually reduces and circumscribes art's possibilities, as we have just seen, by turning art into a special kind of decontextualized object that produces the right sort of inner responses amongst an elite group of art connoisseurs — like Heidegger, I might add — with whom the artworld is populated. Furthermore, Heidegger would deny that aesthetics (even in the broadest sense of the term that encompasses ancient reflections on art, that precedes aesthetics in the narrow, eighteenth century sense) was even around prior to Plato and Aristotle, so its capacity to make art possible was, simply, not possible. In this case, Danto's quasi-transcendental account of the aesthetics/art relationship is, at best, an historically contingent feature of modernity, but certainly not a universal thesis about the theory and practice of art. ${ }^{11}$ 
Stage-setting complete, I want to turn specifically to Heidegger's first lecture course on Nietzsche, The Will to Power as Art. In this text, Heidegger lays out, in a remarkably thoughtprovoking chapter, a set of stages through which the history of aesthetics passes before culminating in Nietzsche's radical (yet, to us, deeply familiar) conception. From the outset, it is clear that Heidegger is keen to contrast aesthetics with great art, which we have already discussed.

In stage one, then, before Plato and Aristotle began writing about it, there was great art in ancient Greece, and as a consequence, there was no need for aesthetics, no need for philosophy to mediate our relationship with art. When we moderns experience art, we typically think of "lived experiences" that are emotionally intense, different from those in our everyday lives. Heidegger bitterly counters that "it was their good fortune that the Greeks had no "lived experiences"” (Heidegger, Nietzsche 80). Those fortunate Greeks simply dwelt in the radiant presence of great art, and had no need to "escape" into art galleries or sculpture gardens.

But this all changed. At stage two, philosophy comes on the scene to tell us what art is, armed with metaphysical concepts like "matter," "form," and "idea." Although seemingly innocuous, Heidegger asserts that the form/matter dichotomy had the effect of transforming the Greek understanding of the creative process itself. According to this interpretation, the Greek word techne originally referred to the knowledge governing our capacity to "bring forth" in a sense broad enough to include both art and craft. This knowledge guided the artist's or craftsman's ability to release possibilities residing, for example, in the wood or stone. But as Heidegger explains, the alignment of "form" with "rationality" required a new relationship to develop between the artists and craftsmen and their (irrational) material. With a form already in mind, the task of making things became no more than the imposition of form upon recalcitrant 
matter, thus reducing the "knowing guidance of bringing-forth" to mere production (Heidegger, Nietzsche 82). ${ }^{12}$ Thus, at the hands of Plato and Aristotle, techne itself undergoes a change, a narrowing, and its meaning is divorced from the disclosure of truth, and thereafter fixed instead to the mere production of beautiful things.

In Plato's notorious account of art in his Republic, we can see evidence of this reduction, evidence that the end of great art was written into the very inception of Western aesthetics. Keeping in mind the ontological-ethical "function" that the Greek temple and Greek tragedy played for the ancient Athenians, we can see how Plato's massively reductive account of how art works and what art can do flies in the face of Heidegger's "pre-Socratic" understanding of great art. Plato claims, after all, that art distorts the truth and leads us away from reality, thereby denying the possibility that art (rather than philosophy) can be truly disclosive. Far from making explicit what is and what matters to the community, art merely confuses and obfuscates by taking us back into the shadowy world of the cave. After denying any cognitive or truth-disclosing role to art, Plato then accuses art of appealing to our emotions, to what is lowest in the soul, and argues that art is, on that account, a genuine danger to the city's well-being. By divorcing art from truth, and attaching it instead to the irrational domain of human feeling, appetite, and emotion (even if only to purge certain emotions, as Aristotle argued), the die was cast. Despite future challenges to, and departures from, Plato's domestication of art, his literal call to remove art from public life, all subsequent reflections on art have fulfilled the cliché and followed along quite dutifully as a series of footnotes.

Between the ancient Greeks and stage three, there is an extraordinary gap of almost two thousand years. Heidegger argues that there were no pivotal developments "for the history of knowledge about art" in Hellenistic, Roman, Medieval or Renaissance eras (Heidegger, 
Nietzsche 83). This stage marks "the beginning of the modern age," the post-Cartesian era in which the beautiful in art is determined by the sorts of feelings the work produces in the observing subject. But exclusive concern with the affectedness of the ego cogito characteristic of modern aesthetics is "concurrent" with, Heidegger notes, "the decline of great art." Paradoxically, in the modern epoch, an historical period that encompasses the work of Bach, Mozart, and Goethe, "art forfeits its essence, loses its immediate relation to the basic task of representing the absolute" (Heidegger, Nietzsche 84). This stage thus coincides with the birth of "aesthetics" in its modern sense at the hands of Baumgarten and Kant in the eighteenth century—although strangely these figures are unnamed in Heidegger's narrative. Aesthetics is now explicitly the field that investigates how our sensations and feelings are related to beautiful objects. What this officially seals and confirms, despite all of the intramural squabbles between the major Enlightenment players, is the irrelevance of art to thought and the disclosure of truth. Art is now a special kind of object that affects the sensing subject in an emotionally heightened way, and art is thereafter judged and evaluated, Heidegger contends, by its very ability to inculcate these specific sorts of aesthetic experiences.

In contrast to the anonymous inauguration of modern aesthetics, the final three stages of Heidegger's history are attached to proper names, and occur, in rapid succession, during a fifty or sixty year period in the nineteenth century. At stage four, modern aesthetics reaches its apotheosis in Hegel's monumental Lectures on Aesthetics. It is this text in which Hegel notoriously claims that art, having lost its capacity as a sensuous presentation of the absolute, has become a "thing of the past." Whatever role art used to play for the ancient Greeks, it has been succeeded logically and historically by religion and philosophy. There is nothing art can tell us about ourselves that cannot be told with greater conceptual precision by philosophers (like 
Hegel). Despite the different philosophical idiom, Hegel's "death of art" thesis clearly anticipates Heidegger's own analysis. But while Hegel's historical-dialectical account quite happily inscribes art's obituary in a larger narrative of progress and the unfolding of reason, Heidegger's sense of loss is palpable:

Hegel never wished to deny the possibility that also in the future individual works of art would originate and be esteemed. The fact of such individual works, which exist as works only for the enjoyment of a few spectators of the population, does not speak against Hegel but for him. It is proof that art has lost its power to be the absolute, has lost its absolute power. (Heidegger, Nietzsche 85)

For Heidegger, what has been lost is great art. The aestheticized art that continues to be made for modern connoisseurs merely confirms Hegel's thesis, as if by implicitly revealing its own lack.

After Hegel's stage four comes Wagner's stage five. Heidegger's treatment of Wagner is considerably longer than his discussions of any of the other five developmental stages. This is perhaps surprising, since Heidegger clearly "knows" less about Wagner than he does about Plato and Aristotle, Kant, Hegel or Nietzsche. He has written at length about these other figures, yet this is his only engagement with Wagner. And Wagner is the only actual (or at least named) "artist" whose contributions - be they theoretical or as artworks-feature in Heidegger's unconventional history. Since it is Heidegger's "confrontation" with Wagner here that constitutes the focus of this paper, I will simply note, provisionally at this point, that Wagner's inclusion in the history of aesthetics is based upon his idea of the "total work of art," and his later elevation of music above the other arts in light of its capacity to express sheer, formless feeling.

It is a small jump only from stage five to stage six, Nietzsche's stage, wherein art is understood as that which is able to arouse us, not just emotionally or, more broadly stated, psychologically, but physiologically. Nietzsche's thought opens the way for artworks to be treated as variable sorts of stimuli capable of generating a range of predictable, bodily responses 
in certain biological organisms. Nietzsche's biological metaphors may well be rhetorical artifacts of the nineteenth century, but there is nothing metaphorical in contemporary neuroscientific studies of music, which attempt to confirm empirically the very relationships between music and physiology that Nietzsche suggests. In these sorts of studies, certain types of music are played for test subjects undergoing a functional MRI in order to determine the connections between different tempos and melodies and, for instance, motor activity, language, or even empathy. The Vertigo example is but a distant prolegomenon of today's research. But for Heidegger, this Nietzschean vision of aesthetics was prepared long ago, as we have seen, by ancient Greek philosophy, and Nietzsche is read not as the opponent of "aesthetic Socratism," but as the unwitting dupe of the very tradition he sought to overcome.

There is a great deal more to be said about all of this. Much of what Heidegger claims here is deeply controversial and quite easily contested. My purpose, however, is not to offer a comprehensive account for this section as a whole; rather, I want to focus much more narrowly on the penultimate stage of this history, Wagner's stage, in order to determine whether Wagner's inclusion within this narrative, and the charges Heidegger levels against him, can at all be justified.

\section{Heidegger's Case Against Music}

If we look back over the history of aesthetics, it is frequently the case that when philosophers focus on art in general, they often focus their reflections upon one artistic genre only—and typically the one they know best. This is certainly true of Heidegger, despite his attempts to stand outside of this tradition. Aside from his remarkable, yet highly idiosyncratic, encounters with Van Gogh paintings and Greek temples, Heidegger's overwhelming 
philosophical interest was in poetry. To cite an exception that only proves this rule, Heidegger gave an address in 1955 to commemorate the $175^{\text {th }}$ birthday of Conradin Kreutzer, a relatively minor German composer, but as with the 1936 discussion of Wagner, there is virtually nothing said about Kreutzer's music, or even Kreutzer himself. The address is rather an occasion for Heidegger to sound off on other themes of his later thought, and thus we learn, for example, that nature has become "a gigantic gasoline station," but nothing about how Kreutzer's music might in any way serve-like Hölderlin's verse — as a bulwark against technological, calculative thought (Heidegger, Discourse 50). Ironically, the address concludes with Heidegger quoting Johann Peter Hebel—a poet.

While Kant may well have compared the experience of music to a fleeting whiff of perfume, his sporadically faithful disciple, Arthur Schopenhauer, set out to invest music with deep metaphysical significance. In fact, Schopenhauer claimed that music has a priority over the representational arts. These other arts engender within their viewers a transformation of their ordinary, conscious state. In this new state of "aesthetic consciousness," our painful, selfinterested immersion in worldly things gives way, and we temporarily become a "pure, will-less, painless, timeless subject of knowledge" (Schopenhauer, World as Will 179). Representational art takes us out of ourselves, out of the particularities of the phenomenal world. The world of will underlying appearances, Schopenhauer explains, now objectifies itself to aesthetic consciousness as Platonic ideas. The observer is led to the universal from the experience of the particular. With music, however, the case is different, and a new theory is required to explain its metaphysical significance. Far from idealizing the objects of everyday perception, Schopenhauer argues that music does not copy the world of empirical representation, but is rather a copy, and thus a direct expression, of the will itself. As such, music is able to speak to us much more 
deeply than the other representational arts, granting us direct access, in nothing but tones, to the innermost being of the world.

Wagner read through Schopenhauer's The World as Will and Representation several times, well after he had already written several operas as well as his important early books on opera theory. ${ }^{13}$ After reading Schopenhauer (beginning in 1854 when Nietzsche was a churchgoing ten year old), Wagner's previously held view — that the different, individual arts enjoyed a state of basic equality within the Gesamtkunstwerk - came to an end. After the encounter with Schopenhauer, Wagner came to see that music had a privileged role to play, even above poetry, in articulating the deep realities of human existence. In a nutshell, Schopenhauer argued that behind the world of phenomena, music could reveal to us that the world was one, that the principle of individuation was merely an illusion concealing a primal, metaphysical unity. If so, music could also reveal that, at a deep metaphysical level, the apparent divisions between people are illusory as well. This insight formed the basis for Schopenhauer's ethic of compassion. As Wagner came to understand, the phenomenal world is the world of separation, individuation, and suffering ending only in death. However, beneath all of this, underlying the false divisions of space and time, is the ceaseless, striving, singular metaphysical will. On the operatic stage, therefore, we can see the sets, costumes and the outward appearance of the actors, but behind these merely phenomenal externalities is the orchestra's music, speaking directly to the noumenal inner lives of the characters before us, and our own inner lives too.

Given this influence of Schopenhauer upon (later) Wagner and (early) Nietzsche, it is telling that Heidegger does not include Schopenhauer within his "history of aesthetics" even though it was Schopenhauer (contra the "poetry-privilegers"-Kant, Hegel, and Heidegger) who provided the metaphysical schema within which the subsequent musical-boosterism could 
flourish. ${ }^{14}$ This Schopenhauerian elevation of music over the other arts is one of the central issues arising in Heidegger's discussion of Wagner.

On the one hand, Wagner's grand ambition to synthesize the disparate arts into his notorious "total work of art" is read by Heidegger as perhaps the one possible nineteenth century counter-claim to the Hegelian "death of art" thesis. If the task of art, as Hegel claims, is the sensuous expression of the absolute, that is, the attempt by sensation alone to communicate what is true for a people, then it is no surprise that this task has been eclipsed historically by religion and (purely conceptual) philosophy. ${ }^{15}$ But if Wagner's operas-intended to be the modern analogues of Greek tragedy_are similarly able to articulate dramatically the deepest, universal truths of our nature on an equally grand scale, then at least they resist easy assimilation into Hegel's art-religion-philosophy developmental schema. Although Heidegger does not elaborate, he does state that "with reference to the historical position of art, the effort to produce the 'collective artwork' remains essential”' (Heidegger, Nietzsche 85). This seems to be the most favourable statement Heidegger makes on Wagner's behalf. ${ }^{16}$ If "for us, art belongs to the past," (Hegel, Aesthetics 11) then in what sense is the Wagnerian complete artwork "essential" unless it somehow calls into question Hegel's thesis? This would at least partly explain why Wagner deserves a stage of his own, so to speak, in the history of aesthetics.

On the other hand, Heidegger quickly zeroes in on the later-Wagner's assessment of the priority of music over the other arts. According to Heidegger, Wagner's operas seek

the domination of art as music, and thereby the domination of the pure state of feelingthe tumult and delirium of the senses, tremendous contraction, the felicitous distress that swoons in enjoyment, absorption in "the bottomless sea of harmonies," the plunge into frenzy and the disintegration into sheer feeling as redemptive. (Heidegger, Nietzsche 86) 
Heidegger clearly connects the domination of music with the domination of feeling. To be fair, there are many passages in Wagner's theoretical writings that support precisely this point. In fact, Heidegger directly quotes a passage from The Artwork of the Future in support of his own claim (see Heidegger, Nietzsche 86). But the more important philosophical argument that Heidegger makes in this section has nothing, really, to do with what Wagner has written or with the sort of music that Wagner composes. Heidegger's basic complaint is a more fundamental argument against the capacity of music itself to do anything more than bestir the soul emotionally. Indeed, what eventually undermines the "collective artwork" is precisely the dominant role that music is assigned, in Wagner's post-Schopenhauerian theoretical works, for the achievement of its dramatic purpose. But for Heidegger, that is not all:

That Richard Wagner's attempt had to fail does not result merely from the predominance of music with respect to the other arts in his work. Rather, that the music could assume such preeminence at all has its grounds in the increasingly aesthetic posture taken toward art as a whole - it is the conception and estimation of art in terms of the unalloyed state of feeling and the growing barbarization of the very state to the point where it becomes the sheer bubbling and boiling of feeling abandoned to itself. (Heidegger, Nietzsche 88 [my italics])

In other words, the dominance of music is merely a symptom of the way in which aesthetics dominates art in the modern era. The ostensibly structureless, Dionysian rapture of Wagner's music that Nietzsche famously criticizes — a criticism Heidegger uncritically accepts—is viewed by Heidegger as the inexorable consequence of Plato's inaugural delimitation of art by philosophy. ${ }^{17}$ Wagner's attempt, although "essential," necessarily "had to fail." According to Heidegger, were it not for the fact that modern aesthetics already demands that artworks be grasped from their capacity to affect the audience, then Wagner's privileging of music over and against the other arts would not have been thinkable. Whether this is yet another concealed attack on Schopenhauer is unclear, but it is shocking to think that Heidegger believes that music, in 
principle, can serve no other ends than what the modern age has metaphysically prescribed through its aesthetic theory.

There is clearly a strong circumstantial case to be made that, from Heidegger's point of view, there can be no great musical art. First, as the passages on Wagner suggest, there is something about music itself, not just Wagner's music, as Heidegger makes clear, that reinforces the contrast between inner feeling and the outer world - a contrast that virtually defines the subjectivism of the modern epoch. Any art form, consequently, that gives preeminence to music, accordingly, will thus reproduce and potentially exacerbate, rather than resist, the subject/object division that underwrites the way we moderns have come to experience all types of art. This means that had Wagner stuck to his early theoretical claims about the equality of the individual arts within his musical dramas, then his attempt to produce great art would not obviously have "had to fail." Now, Heidegger is certainly not claiming that a musical component automatically disqualifies an art work from the status of greatness, but the clear suggestion is that the music must play a supporting role to a poetic text.

Second, as Julian Young points out, Heidegger's theoretical point here coincides exactly with what we know of his own musical tastes. Heidegger admired Orff's Carmina Burana and Stravinsky's Symphony of Psalms, for instance, wherein the music arguably heightens and stresses the emotional complexions of the written word, but nowhere is Heidegger on record expressing any esteem for purely instrumental or "absolute" music from any period whatsoever (see Young, Philosophy of Art 169). There is no reason to conclude, therefore, that opera, in principle, cannot count as great art. But certainly Wagner's last five operas, and any other complex, multi-genre art work in which music plays the dominant role, are pre-ordained to fall short of this goal. 
Without doubt, Heidegger is engaged in a philosophical struggle with Schopenhauer, Wagner, and Nietzsche over the respective significance of music and poetry. The truly polemical nature of Heidegger's engagement with Wagner must, in the end, be appreciated in light of this broader context: "Rising on the swells of feeling would have to substitute for a solidly grounded and articulated position in the midst of beings, the kind of thing that only great poetry and thought can create" (Heidegger, Nietzsche 88 [my italics]). In other words, there can be no dialogue, for Heidegger, between music and thinking. Music cannot think. Therefore, only poets like Hölderlin and Heidegger are capable of responding to the spiritual destitution of the modern age. But Heidegger's confrontation with music is not just about this epochal malaise and different possible futures; it is also possibly a surreptitious argument about the role music did or did not play in Heidegger's paradigmatic example of pre-aesthetic great art: Greek tragedy.

\section{Heidegger, Wagner and Greek Tragedy}

Question: in addition to being either Greek or German, what did all the named individuals in Heidegger's developmental history of aesthetics have in common? Answer: a deep and abiding interest in Greek tragedy. Plato, Aristotle, Hegel, Wagner and Nietzsche have each contributed enormously influential interpretations of Greek tragedy, and Heidegger himself was clearly immersed in his own study of the ancient tragedians at this very moment of his philosophical life (an engagement probably sparked by Hölderlin's philologically unorthodox translations of Sophocles). For Heidegger, Greek tragedy exemplifies great art-a great art that was only possible because it flourished prior to the emergence of aesthetics, broadly construed. Heidegger's Auseinandersetzung with these figures and his larger project of overcoming aesthetics will thus in part be waged over their differing appropriations of the essence (is it music 
or poetry?) of Greek tragedy. Wagner, however, is a special case. Not only does he write at considerable length about Greek tragedy, but we also have overwhelming evidence at hand to conclude that Wagner saw his own work - the Ring Cycle especially—as a modern continuation of Aeschylus. ${ }^{18}$

So how did Wagner understand Greek tragedy, and how did he understand his own work in relation to it? First, what is striking about Wagner's description of Greek tragedy is that it remarkably prefigures Heidegger's own view of great art, as discussed earlier. Here is a representative passage from Art and Revolution, published in the wake of the failures of 1848:

With the Greeks the perfect work of art, the Drama, was the abstract and epitome of all that was expressible in the Grecian nature. It was the nation itself - in intimate connection with its own history - that stood mirrored in its art-work, that communed with itself and, within the span of a few hours, feasted its eyes with its own noblest essence. (52)

Wagner's notion, here, that tragedy works by mirroring back to the Greeks their own noblest (a normative term) essence, making their world explicit to them, is at least roughly consistent with Heidegger's claim about the Greek temple: that it gave things their look, and gave men an outlook on themselves. In other words, for Wagner and for Heidegger, the work tells the truth about a people; it is "disclosive" in the broadest sense. It is also crucial to note that it was "the nation itself," the Greek people as a whole, who were involved in the performance. Tragedy was a serious art, performed during religious holidays at the state's expense. It was, accordingly, a public art—not just a privileged experience for Greek aristocrats and drama-enthusiasts.

Additionally, Wagner's and Heidegger's respective accounts line up because both acknowledge a connection between the artwork and the historical world it mirrors and reveals. As we have seen, Heidegger claims that the Greek temple can only be great art if the very world it nourishes and sustains exists as well. So if the world "ends," the artwork will die too. Wagner 
believes something very close to this as well, for he offers his own political reading of the "death of tragedy," long before Nietzsche came into his life.

According to Wagner, during the Golden Age of ancient Greece, the unity of the city was recapitulated in the unity of the drama. But then, as the Greek poleis began to break down and fragment in the $4^{\text {th }}$ century BCE, tragedy also broke up into its constituent artistic genres. ${ }^{19}$ Before this, Greek tragic drama prefigured Wagner's Gesamtkunstwerk, the "total" or "complete work of art" that combined the individual arts into a seamless, integrated dramatic performance. However,

With the subsequent downfall of Tragedy, Art became less and less the expression of the public conscience. The Drama separated into its component parts; rhetoric, sculpture, painting, music, \&c, forsook the ranks in which they had moved in unison before; each one to take its own way, and in lonely self-sufficiency to pursue its own development. (Wagner, Art and Revolution 52)

Tragedy thus died a political death. But the implicit point here is that even though we moderns may have copies of the extant tragedies on our bookshelves, and may well go to contemporary performances of the plays, the dramas clearly no longer serve their original historical purpose of articulating the ontological-ethical framework - the world of gods and mortals - to the ancient Greek community. Like Heidegger, Wagner is (more or less) clear that this possibility is long gone: this explains why modern Germany needs an artist like Wagner.

Thus, just as political fracture prepares the way for artistic disintegration, Wagner's operas, having gathered up the component artistic genres from their "lonely self-sufficiency," point toward the political unification of Germany in 1870 . Wagner could thus serve the new state as a latter-day Aeschylus - a dramatist who could draw upon a cultural storehouse of indigenous myths in order to tell his fellow Germans something important about themselves. The historical moment for another "birth of tragedy" was at hand. But having read Schopenhauer in the 1850s, 
Wagner came to realize that the disparate arts could not just "come together" on equal terms. Music alone has a clear privilege and priority. Given its unique capacity to reveal the metaphysical will, tragedy would need to be re-born, if at all, "out of the spirit of music."

Nietzsche's more familiar account of the birth and death of tragedy transforms Wagner's political story into a compelling philosophical narrative. ${ }^{20}$ Greek tragedy, as Wagner had previously claimed, was the child of both Dionysian and Apollonian energies underlying the cultural life of the ancient Greeks. The irrational, intoxicating Dionysian element- the musicwas given expression in the beautiful Apollonian dream-world of the theatre. There the Greeks were able to confront life's terrors and cruelties without desiring to flee from them into some higher, ostensibly redeeming, reality. Instead, their tragedy enabled them to confront existence for what it was, yet affirm life, say "yes" to everything, despite the inevitability of horrible suffering. Tragedy thus afforded the possibility of "this-worldly" redemption. But it was Euripides, the artistic mask concealing the Cyclops-stare of Socratic reason, who drove Dionysus from the orchestra, transforming ancient drama into yet more rational argument, more grist for the dialectician's mill. It was thus Nietzsche who offered the first proto-argument suggesting that aesthetics, personified by the unmusical Socrates, killed great art (while simultaneously discerning its re-birth in his best friend's operas).

So what happens to Heidegger's thesis if Wagner and Nietzsche - the two figures who represent the apotheosis of Western aesthetics - are right about the musical basis of Greek tragedy? Certainly, if the musical chorus was the womb out of which tragedy developed and is essential to it (and not just a pleasing delivery-system for the poetry), then music cannot simply be reduced to a genre of "aesthetic" art, as Heidegger argues. If it was once crucial to the production of great art, if it can be truth-disclosing and not simply feeling-arousing, then 
Heidegger's critique falls wide of the mark. For Heidegger to admit that music actually made great art possible would be the equivalent of Augustine admitting that Adam and Eve were steeped in sin before encountering the serpent and eating forbidden orchard fruit.

It is for this reason that Heidegger goes out of his way in his 1942 lecture course on Hölderlin's “The Ister” to stamp out Nietzsche's (circuitously pro-Wagner) claim that tragedy developed "out of the spirit of music." While Nietzsche and Wagner are not named in the few passages Heidegger devotes to the origins of tragedy, his intentions and targets could not be mistaken. While apparently conceding the thesis that tragedy arose from the musical chorus, Heidegger reinterprets this to mean something entirely antithetical to Nietzsche's thesis:

The fact that Greek tragedy in general arose from the "chorus" says, when thought in an essential manner, nothing other than the fact that the chorus is the inner middle of the poetizing of tragedy as poetizing. And the choral ode of the completed, tragic work is in turn the middle of this middle. (Heidegger, Ister 118)

There is no need for Heidegger to state explicitly that music is not, accordingly, the womb out of which the tragedy developed, for that is implied by his argument that the chorus is in essence poetic, and thus constitutes the center of the tragedy's "poetizing."

Certainly, we know that Heidegger was preoccupied by the great choral ode in Antigone both in the Hölderlin lecture course and in Introduction to Metaphysics, published seven years earlier. However, in both texts his attention is focused exclusively on teasing the meaning from Sophocles' poetic language: the choral nature of the ode was beside the point, as if the lyrics of a song could be interpreted without worrying about the melody or tempo. Heidegger's italicization of "ode" in the following passage emphasizes yet again the priority of the poetry in tragedy, regardless of why or how tragedy came into being:

The chorus is not simply the origin of tragedy in terms of its "developmental history;" rather, in the choral ode, the chorus becomes the essential middle of the tragedy in terms 
of the history of its essence. This essential middle poetically gathers around it the whole of the poetic work; the chorus is that which is to be poetized. (Heidegger, Ister 119)

Heidegger's targets are, once again, unmistakable. He is clearly out to contest, at least implicitly, any claim that tragedy can be grasped adequately by appealing to its developmental history. In other words, we would still misunderstand what tragedy is essentially, even if it were true that tragedy could be traced back to early musical performances, as Nietzsche argued.

Heidegger is obviously not denying a musical component in Greek tragedy, and at no time does he claim, as he did of Wagner's later work, that Greek tragedy would have "had to fail" as great art if music had been the dominant artistic genre. But for Heidegger, whatever role music played for the pre-Platonic ancient Greeks, it was not essential to the greatness of their tragedies. This view is consistent with everything else Heidegger has written about modern music, as we have seen, and we might wonder whether he viewed music as already freighted with all of the metaphysical baggage that the other genres of art would later take on under the sway of modern aesthetics.

Perhaps the real tragedy of Heidegger's view of music is that it potentially undermines his own very powerful argument against aesthetics itself. Heidegger has a story to tell—perhaps not the right one-about how art has been diminished in scale and purpose in practice by virtue of aesthetic theory, but if this irredeemably aesthetic genre was at the core of a type of great art that flourished prior to the emergence of aesthetics, then Heidegger's narrative cannot easily hold together. Consigning Wagner and Nietzsche to the history of aesthetics thus helps Heidegger to explain away their reading of tragedy, and what a rebirth of tragedy might look like in the modern age. Of course they "discovered" a musical origin and essence in Greek tragedy, Heidegger seems to say; what else could we expect from a pair of Western aestheticians? ${ }^{21}$ 
While Heidegger falls in with a long line of philosophers for whom different artistic genres are unequal in rank, his exceptionless relegation of music and championing of a more "logocentric" poeticizing, has the unwitting consequence of situating Heidegger in the proximity of a Platonic philosophical tradition that he is attempting to overcome.

\section{Conclusion: To the Operas Themselves!}

As Heidegger's readings of various modern poets and his phenomenological interpretation of Van Gogh's A Pair of Shoes make clear, Heidegger is not simply interested in "great art," like tragedy, that has the revolutionary potential to transform a community's sense of itself and the world around it. More modestly, some exemplary artworks have the capacity to disclose how art itself "works" by illuminating the "essential strife" between "world" and "earth," the dynamic process through which truth is both revealed and concealed (Heidegger, "Origin" 49). According to Heidegger, Van Gogh's painting discloses this process by both revealing to us the meaningful world of the farmer's shoes, while also resisting our attempts to make this world completely intelligible. Because of the "essentially self-secluding" earth, the painting can help us to appreciate that meaning itself can never be exhausted, that there are always interpretive possibilities that we have yet to even fathom (Heidegger, "Origin" 47). Heidegger thus tries to show that even artworks, like Van Gogh's painting, which might appear to be the ideal-typical exhibits of modern aesthetics, can actually help us see how modern aesthetic approaches to art actually impede our hermeneutical access to how artworks themselves “work," ontologically speaking. ${ }^{22}$

In this final section, accordingly, I want to argue that Wagner's Ring can also be interpreted as an exemplary modern artwork, one that likewise reveals to us, through the music, 
that we can never master and control all meaning. Indeed, despite the demands for mastery and control that govern both our world and the world on display in Wagner's four musical dramas, we are able, as listeners, to hear the characters struggle, without ever fully succeeding, to make their world intelligible. ${ }^{23}$ It is this structural tension within intelligibility itself, the dynamic process of revealing and concealing, that Wagner is able to capture so remarkably with his music.

In scene four of Das Rheingold, when Erda, the Earth goddess, tells Wotan that "Alles was ist, endet," ["all that is shall come to an end"] there are two possible ways in which this claim can be taken (Wagner, Rheingold). First, it can be read superficially as the claim that everything will eventually be destroyed, that being will one day become nothing. Second, it can be read as a more nuanced thesis about the finitude of the world ruled over by Wotan and the other gods of Valhalla. This interpretation suggests that after the "twilight of the gods," after the Rhine has overflowed its banks and washed the old world away, another world will take its place. We know, of course, that Wagner wrote and re-wrote the ending of the Ring several times, and much ink has been spilt to explain the ending of, and meaning of, the entire tetralogy. ${ }^{24}$ But this second interpretation surely has a Heideggerian "ring" to it, for it suggests that the happening of truth is historically finite, that a world — any world — stands within a particular horizon of disclosure over which we have no control, but which nevertheless governs our understanding of "what is and what matters" to us (Thomson 43).

Das Rheingold begins with the famous leitmotif of nature, a very dignified, slowly rising arpeggio played on the horns, and we witness a world coming-into-being out of nature directly before us. ${ }^{25}$ We hear variations of this motif in later operas-from the Rhine motif that quickly unfolds, to the "forest murmurs" motif in Seigfried, to the "world ash-tree" motif of 
Götterdämmerung. When we hear these subsequent variations and transformations, our experience of the world revealing itself before us is immediately transformed: what we hear in the present turns us back to the past, and anticipates a coming future. The music thus "temporalizes" the world, disclosing it as a finite and limited structure of meaning, just one way for being to reveal itself amongst limitless possibilities. This is in contrast to a metaphysical determination of being which conceals, to borrow Young's phrase, "the projected character of world," the idea that our basic experience of reality and what matters to us can fundamentally change (Young, Philosohy of Art 161). Metaphysics, recall, passes off one possible mode of world-disclosure as universal, absolute. Wagner's Ring does the opposite. As listeners, we are constantly reminded - often by the music alone-of the beginning and end of the world throughout the entire fourteen hour performance. Instead of simply enforcing the ontologicalethical framework of the world presented in the Ring, at a deeper level Wagner's semantically dense music is constantly suggesting to us that the world on stage is an historically contingent dispensation of being - just as the modern world itself is. Consequently, when Erda emerges from the Earth to speak with Wotan, to tell him that his rule from Valhalla will not last, it is the nature motif that we hear once more. But this time, it is played in a minor key, and the majestic, rising notes of its first iteration are inverted to communicate the eventual decline of the gods. The orchestra tells us this; Erda's words are almost superfluous.

While I cannot do justice to even this one, small detail of the Ring, it is worth mentioning, since it so clearly shows that Wagner's music is far more subtle and sophisticated than his musical theory. ${ }^{26}$ But it also suggests that his music, if my interpretation is on the right track, cannot be so hastily construed as the high moment of modern aesthetics, given the way it resists assimilation within this tradition. Once we attend to the fact that Wagner's music is not 
simply functioning to stimulate the emotions of a distracted, bourgeois audience, but is able to show us that the world within which art has been assigned this restricted role is itself a finite, historical world, then we have good reason to think of Wagner's art more as "saving power" and less as "danger." One does not have to do violence to Wagner's operas to make them speak a Heideggerian language-game.

But if that is true, then perhaps Wagner's operas present us with a new type of modern, post-aesthetic art altogether. After all, while they may well have interesting things to tell us about power, violence, love, redemption, and the contradictions of European modernity, they are not simply doing for us what the Greek temples or tragedies did for the Greeks. Instead of functioning as an ontological paradigm of the modern age, Wagner's operas likewise point toward a deeper, Heideggerian understanding of what a world is in the first place. In other words, by revealing the ineliminable historicity of all ontological paradigms, Wagner's operas make the Heideggerian point that being itself is inexhaustible, that however much we try, as Wotan did, to control things, to make the world transparently intelligible, our efforts will fail. But despite this failure, Wagner's operas show us that our inability to master all meaning is actually a condition for the possibility of having meaning at all. And if that is true, then there must be more to music than meets the Heideggerian ear.

\section{Notes}

1 Aside from Nietzsche's well-known books, see also Theodor Adorno, In Search of Wagner, Alain Badiou, Five Lessons on Wagner, Philip Kitcher and Richard Schacht. Finding an Ending: Reflections on Wagner's Ring, Philippe Lacoue-Labarthe, Musica Ficta: Figures of Wagner, Bryan Magee, The Tristan Chord: Wagner and Philosophy, Michael Tanner, Wagner. See also the essays on Wagner in Bernard Williams, On Opera. 
All of these authors have helped me to understand Wagner philosophically, and I have also benefitted from the help of an anonymous referee, and personal correspondences with Julian Young, Iain Thomson, and Kent Enns (who commented on an earlier presentation of this paper).

${ }^{2}$ Lacoue-Labarthe is the one exception.

${ }^{3}$ In this paper, I will only be considering Heidegger's reflections on art (and metaphysics) primarily from this brief period in the mid-1930s. For a superb introduction to this topic and to the changes in Heidegger's position, see Julian Young's Heidegger's Philosophy of Art. I am deeply indebted to this exemplary study.

${ }^{4}$ This, of course, is the subtitle of The Birth of Tragedy.

${ }^{5}$ For the sake of convenience, I will use the terms "musical drama" and "opera" interchangeably in this paper, even though Wagner himself did not approve of ascribing the latter term to his works.

${ }^{6}$ Alain Badiou has a nice overview of these proxy-wars in cultural politics. See his Five Lessons in Wagner (56).

7 It is worth recalling the well-known thematic connections between Hitchcock's Vertigo and Wagner's Tristan und Isolde. Musically speaking, the square and rather passionless Midge is associated with Bach and Mozart, whereas Bernard Herrmann has given the lovers, John and Madeline, a score that blatantly references the famous Liebestod from Tristan.

${ }^{8}$ For a sophisticated reading of Heidegger's "rhetoric of greatness" at this time, see Robert Bernasconi, "The Greatness of the Work of Art" in Heidegger in Question: The Art of Existing.

${ }^{9}$ The term "cultural paradigm" comes from Hubert Dreyfus' very influential reading of "Origin of the Work of Art." See his article, "Heidegger on the Connection Between Nihilism, Art, Technology, and Politics" in The Cambridge Companion to Heidegger.

${ }^{10}$ See Young, Heidegger's Later Philosophy (5-30) especially.

${ }^{11}$ The general philosophical claim that aesthetics is somehow antithetical to art has been taken up and criticized most forcefully by Jacques Rancière in Aesthetics and its Discontents.

${ }^{12}$ For a more thorough discussion of the form/matter distinction especially, see Heidegger, “Origin" (26-30).

${ }^{13}$ To be specific, Wagner had composed his first three canonical (post-Rienzi) works before reading Schopenhauer, and had already completed the libretto for the Ring. This first encounter with Schopenhauer occurred while Wagner was composing the music for Die Walkyrie, and its 
musicological fall-out has been the subject of intense debate amongst scholars of the Ring especially.

${ }^{14}$ Of course, there may well be other not-so-philosophical reasons for Heidegger's oversight. In the 1936 Nietzsche lectures, Heidegger chastises Schopenhauer for his superficial (mis)reading of Kantian "disinterestedness,"(see Heidegger, Nietzsche 107-14) but we should also recall that Schopenhauer, a German philosopher, was mixing his Kant with Buddhism and Eastern thought, and so my hunch is that this too may well be an unspoken reason for Heidegger's sin of omission.

15 This is a brief gloss of Hegel's highly compressed definition of beauty in his Lectures on Aesthetics. Specifically, he writes that "the beautiful is characterized as the pure appearance of the Idea to sense" (Hegel, Aesthetics 111).

${ }^{16}$ Heidegger's remarks here are certainly more favourable than those offered by Kant. In $\S 52$, "On the Combination of the Fine Arts in One and the Same Product," Kant suggests that although the combination of the fine arts in, say, tragedy, may well make the work "even more artistic," he is suspicious that the mutual interference of the various arts may ultimately compromise the overall beauty of the "product" (see Kant, Critique of Judgment 195).

${ }^{17}$ It is worth noting that many of Heidegger's critical remarks about Wagner in this section come straight from the mouth of the late Nietzsche, whose personal polemics are notoriously unreliable and shed very little light, ultimately, on Wagner's operatic work itself. I cannot think of another example of Heidegger "out-sourcing" his philosophical judgments in this fashion. One possibility is that Heidegger is prudently using Nietzsche to criticize Wagner for political reasons. Iain Thomson suggests that the entire chapter on the history of aesthetics is drawn from Nietzsche, and should not be passed off strictly as Heidegger's position (see Thomson 47). While I agree that the discussion of Wagner has a clearly Nietzschean slant, I think Thomson's more general claim is too strong, and certainly cannot account for Heidegger's very critical interpretation of Nietzsche himself in stage six.

${ }^{18}$ Indeed, there are remarkable similarities between The Oresteia and the Ring. Both derive their subject matter from indigenous myths; both depict multigenerational stories of human development and evolution; both are concerned with fate, justice and the legitimacy of authority; both contain little "action" but are largely occupied with pondering action or reflecting upon its meaning and consequences; and in both, rarely do we see more than a few characters on stage at once. We forget when we read Aeschylus that much of the poetry was meant to be sung. And when we listen to Wagner, we note that the music is continuous, unfolding, developing its motifs patiently over many hours. Unlike in earlier opera, Wagner is not interested in alternating between dry recitative and melodic arias, duets and choruses ("numbers" to be followed by applause - the staple of most contemporary musicals), for this merely undermines the overall dramatic urgency and seriousness of the work. For an outstanding overview of the Wagner/Aeschylus connection, see Lee, Athena Sings (27-32 especially). 
${ }^{19}$ Wagner's account of tragedy's decline is too much of a "just so" story to be taken seriously. Tragedy flourished for a full century in the wake of Cleisthenes' democratic reforms, which may be read as attempts to direct the loyalties of Athenian citizens away from family and clan, and toward the city itself. Thus, many of the greatest tragedies help Athenians to reflect upon just where their loyalties should now lie. In this light, we can appreciate why Antigone is such an exemplary work, and why such a play (and tragedy in general) would have been taken so seriously by German thinkers especially.

20 In what follows, I am (inadequately) summarizing the first 15 sections of The Birth of Tragedy.

${ }^{21}$ It is no surprise that Nietzsche and Wagner favoured the early dramas of Aeschylus wherein the musical chorus takes centre stage at the expense of action and characterization, while Heidegger preferred Sophocles, who significantly reduced the role of the chorus and the musical content of the dramas.

${ }^{22}$ For the most charitable and insightful reading of Heidegger's interpretation of the Van Gogh painting, see Thomson (65-120).

23 According to Heidegger, Nietzsche's ontotheological determination of being as eternally recurring will-to-power tells us what and how all entities are in the late-modern age. Beings, including human beings, thus show up as merely "resources" to be put to work, optimized by technological organization. We see this quite metaphysical view at work in Wagner's Ring as well. After all, so much of the action is organized around the pursuit of power for its own sake. It is telling that none of the characters really does much with the gold or the ring once possession has been taken. The recent Canadian Opera Company's staging of the Ring somewhat heavyhandedly brought out this point by setting much of Götterdämmerung in a corporate boardroom.

${ }^{24}$ In addition to Kitcher and Schacht's book, see also Slavoj Žižek, "Brünnhilde’s Act.”

${ }^{25}$ Wagner's famous leitmotifs are musical phrases that are associated with persons, emotions, objects, etc. As Bryan Magee clearly explains (pace Heidegger), "what is most interesting of all about this to a serious student of philosophy is that it involves a means of articulating ideas; and moreover a means which, at its most refined, is more particularized, more precise, more subtle and more sophisticated than words" (Magee, Tristan Chord 116).

26 The same criticism can be leveled against Tolstoy. Certainly, we do not think that Tolstoy's novels are great - potentially examples of "great art"-because they conform to his ludicrously simplistic "infection" theory of art. Tolstoy's theory, incidentally, fits beautifully with Heidegger's critique of modern aesthetics. 


\section{Works Cited}

Adorno, Theodor. In Search of Wagner. Trans. Rodney Livingstone. London: Verso, 2005.

Badiou, Alain. Five Lessons on Wagner. Trans. Susan Spitzer. London: Verso, 2010.

Bernasconi, Robert. Heidegger in Question: The Art of Existing. Atlantic Highlands, NJ: 1993.

Danto, Arthur. “The Artworld.” Journal of Philosophy Vol. 61, No. 19 (1964): 571-84.

Dreyfus, Hubert. "Heidegger on the Connection Between Nihilism, Art, Technology, and Politics" in The Cambridge Companion to Heidegger. Ed. Charles Guignon. Cambridge: Cambridge University Press, 1993, 289-316.

Hegel, G. W. F. Aesthetics: Lectures on Fine Art. Tran. T. M. Knox. Oxford: Clarendon Press, 1975.

Heidegger, Martin. Discourse on Thinking. Trans. John M. Anderson and E. Hans Freund. New York: Harper Torchbooks, 1966.

—. Hölderlin's Hymn "The Ister." Trans. Will McNeill and Julia Davis. Bloomington: Indiana University Press, 1996.

- Nietzsche Vol. 1: The Will to Power as Art. Trans. D. Krell. San Francisco: Harper Collins, 1991.

—. "Origin of the Work of Art" in Poetry, Language, Thought. Trans. A. Hofstadter. New York: Harper \& Row Publishers, 1971, 15-87.

Kant, Immanuel. Critique of Judgment. Trans. Werner S. Pluhar. Indianapolis: Hackett Publishing Company, 1987.

Kitcher, Philip and Schacht, Richard. Finding and Ending: Reflections of Wagner's Ring. Oxford: Oxford University Press, 2004.

Lacoue-Labarthe, Philippe. Musica Ficta: Figures of Wagner. Stanford: Stanford University Press, 1994.

Lee, M. Owen. Athena Sings: Wagner and the Greeks. Toronto: University of Toronto Press, 2003.

Magee, Bryan. The Tristan Chord: Wagner and Philosophy. New York: Henry Holt and Company, 2000. 
Nietzsche, Friedrich. The Birth of Tragedy. Trans. Walter Kaufmann. New York: Vintage Books, 1967.

Rancière, Jacques. Aesthetics and its Discontents. Trans. Steven Corcoran. Cambridge: Polity Press, 2009.

Shopenhauer, Arthur. The World as Will and Representation, Vol. 1. Trans. E. F. J. Payne. New York: Dover Publications, 1969.

Tanner, Michael. Wagner. London: Harper Collins, 1996.

Thomson, Iain. Heidegger, Art, and Postmodernity. Cambridge: Cambridge University Press, 2011.

Vertigo. Dir. Alfred Hitchcock. 1958. Universal Studios Collector's Edition, 1999. DVD.

Wagner, Richard. The Art-Work of the Future and Other Works. Trans. W. Ashton Ellis. Lincoln: University of Nebraska Press, 1993.

—. Das Rheingold. The Metropolitan Opera Orchestra. Dir. James Levine. Deutsche Grammophon, 1989.

Williams, Bernard. On Opera. New Haven: Yale University Press, 2006.

Young, Julian. Heidegger's Later Philosophy. Cambridge: Cambridge University Press, 2002.

—. Heidegger's Philosophy of Art. Cambridge: Cambridge University Press, 2001.

Žižek, Slavoj. "Brünnhilde’s Act.” International Journal of Zizek Studies. Vol. 4, No. 0 (2010): $1-44$. 